\title{
IMPLEMENTASI KEBIJAKAN PERLINDUNGAN KONSUMEN SEGMEN OBAT DAN MAKANAN DI KOTA MAKASSAR
}

\section{IMPLEMENTATION OF MEDICINE AND FOOD SEGMENT CUSTEMER PROTECTION POLICY IN THE CITY MAKASSAR}

\author{
A.Jusriadi ${ }^{1}$ \\ Yayasan Pendidikan Al \\ Azhar Pusat Sinjai ${ }^{1}$ \\ Email: \\ ayusriadi77@gmail.co \\ $\underline{\mathrm{m}}$
}

Muhammad Zulqifli ${ }^{2}$ STISIP 17 Agustus 1945 Makassar $^{2}$

\section{A.M Azhar \\ Aljurida $^{3}$ \\ Universitas Indonesia \\ Timur ${ }^{3}$ \\ Email: \\ azharaljurida51@gmail. com}

IJI Publication p-ISSN: 2774-1907 e-ISSN: 2774-1915 Vol.1, No.1, pp.11-20, Nopember 2020

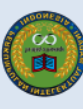
Unit Publikasi Ilmiah Intelektual Madani Indonesia
Abstrak: Penelitian ini bertujuan untuk mengkaji Implementasi Undang-Undang No 8 Tahun 1999 Tentang Perlindungan Konsumen khusus segmen konsumen obat dan makanan di Kota Makassar dengan menggunakan teori Edward III (1980). Metode penelitian yang digunakan yakni pendekatan kualitatif yang bertujuan untuk mengungkap dan menyajikan kembali situasi dan keadaan yang sebenarnya mengenai peran pemerintah dalam mengimplementasikan kebijakan. Hasil penelitian menunjukkan bahwa dari aspek komunikasi Pemerintah Kota Makassar melalui Dinas Perindustrian dan Perdagangan memberikan edukasi dan pemahaman akan pentingnya pengetahuan konsumen mengenai hak-haknya, dari Aspek sumber daya belum mampu menunjang implementasi disebabkan kuantitas pegawai yang terbatas. Namun jangkauan kerja sangat luas, dari Aspek Disposis/Sikap Implementor. Dinas perindustrian dan Perdagangan Kota Makassar menerapkan konsep reward sebagai motivasi bagi pegawai jika memiliki kinerja baik dalam memberi perlindungan pada konsumen, aspek struktur birokrasi, Pemerintah Kota Makassar melibatkan beberapa stakeholder lintas instutusi yang memiliki kesamaan tujuan untuk bersama-bersama melaksanakan kegiatan perlindungan konsumen.

Kata Kunci: Implementasi; Perlindungan Konsumen; Obat dan Makanan.

Abstract: This study aims to examine the implementation of Law No. 8 of 1999 on Consumer Protection specifically for the drug and food consumer segment in Makassar City using the theory of Edward III (1980). The research method used is a qualitative approach that aims to reveal and present the actual situation and circumstances regarding the role of government in implementing policies. The results showed that from the aspect of communication, the Makassar City Government through the Industry and Trade Office provided education and understanding of the importance of consumer knowledge about their rights, from the aspect of resources not being able to support implementation due to the limited number of employees. However, the scope of work is very broad, from the Aspect of Disposition / Attitude of Implementers. The Makassar City Industry and Trade Office implements the concept of reward as motivation for employees if they have good performance in protecting consumers, aspects of bureaucratic structures, Makassar City Government involves several cross-institutional stakeholders who have the same goal to jointly carry out consumer protection activities.

Keywords: Implementation; Consumer Protection; Medicine and Food.

\section{PENDAHULUAN}

Indonesia dibawah pemerintahan Presiden BJ Habibie pada 20 April 1999 telah menandatangi Undang-Undang Nomor 8 Tahun 1999 tentang Perlindungan Konsumen sebagai regulasi yang dihadirkan untuk memberi rasa aman kepada masyarakat dalam mendapatkan haknya sebagai konsumen. Selain itu, sejumlah perangkat hukum lainnya pun sebenarnya sudah disahkan, mulai dari pembentukan Badan Perlindungan Konsumen Nasional (BPKN), Badan Penyelesaian Sengketa Konsumen (BPSK), dan Lembaga Perlindungan Konsumen Swadaya Masyarakat (LPKSM). Sejak awal Pemerintahan era reformasi, tampak ada keperdulian terhadap perlindungan konsumen. Sampai saat ini, pelaksanaan perlindungan konsumen masih dirasakan masyarakat sangat minim.

Secara umum masalah perlindungan konsumen atas barang dan jasa yang beredar di dalam negeri seperti yang diamanatkan dalam Undang-Undang Perlindungan Konsumen tampaknya tidak terlaksana dengan baik dan diperlukan kerja keras semua pemangku kepentingan untuk memberikan pendidikan konsumen obat dan makanan melalui program-program yang lebih efektif, konsumen sendiri oleh Hornby (Nasution, 1998), diartikan sebagai seseorang yang membeli barang atau menggunakan 
jasa. Seseorang atau suatu perusahaan yang membeli barang tertentu atau menggunakan jasa tertentu.

Faktor utama yang menjadi kelemahan konsumen obat dan makanan adalah tingkat kesadaran konsumen akan haknya masih rendah. Hal ini terutama disebabkan oleh rendahnya pendidikan konsumen. Oleh karena itu, kebijakan tentang Perlindungan Konsumen pada segmen obat dan makanan yang dimaksudkan menjadi landasan hukum yang kuat bagi pemerintah dan lembaga perlindungan konsumen swadaya masyarakat untuk melakukan upaya pemberdayaan konsumen melalui pembinaan dan pendidikan konsumen. Upaya pemberdayaan ini penting karena tidak mudah mengharapkan kesadaran pelaku usaha yang pada dasarnya prinsip ekonomi pelaku usaha adalah mendapat keuntungan yang semaksimal mungkin dengan modal seminimal mungkin. Prinsip ini sangat potensial merugikan kepentingan konsumen, baik secara langsung maupun tidak langsung.

Upaya-upaya yang berkaitan dengan gerakan perlindungan konsumen sudah mulai bergema sejak tahun 1970 an terutama sejak berdirinya Yayasan Lembaga Konsumen Indonesia (YLKI) pada bulan Mei 1973, sebagai lembaga "independent" yang mengkhususkan menyangkut kepentingan konsumen. Namun demikian, beberapa tahun terakhir ini kerugian konsumen masih saja terjadi di mana-mana, karena banyaknya konsumen yang tidak melaporkannya kepada aparat. Sebelum munculnya UndangUndang Perlindungan Konsumen yang diberlakukan pemerintah mulai 20 April 2000, yang merupakan "undang-undang payung (umbrella act)" di bidang perlindungan konsumen, praktis hanya sedikit pengertian normatif yang tegas tentang konsumen dalam hukum positif Indonesia. Dalam garis-garis besar haluan negara disebutkan kata konsumen dalam rangka membicarakan tentang sasaran bidang perdagangan, sama sekali tidak ada penjelasan lebih lanjut tentang pengertian istilah ini dalam ketetapan tersebut.

Resolusi Perserikatan Bangsa-Bangsa Nomor 39/248 Tahun 1985 tentang Perlindungan Konsumen (Guidelines for Consumer Protection), juga merumuskan berbagai kepentingan konsumen yang perlu dilindungi, yang meliputi: 1) Perlindungan konsumen dari bahaya terhadap kesehatan dan keamanannya. 2) Promosi dan perlindungan kepentingan ekonomi sosial konsumen 3) Tersedianya informasi yang memadai bagi konsumen untuk melakukan pilihan yang tepat sesuai kehendak dan kebutuhan pribadi 4) Pendidikan konsumen 5) Tersedianya upaya ganti rugi yang efektif 6) Kebebasan untuk membentuk organisasi konsumen atau organisasi lainnya yang relavan dan memberikan kesempatan kepada organisasi tersebut untuk menyuarakan pendapatnya dalam proses pengambilan keputusan yang menyangkut kepentingan mereka.

Atas dasar kondisi sebagaimana dipaparkan di atas, maka dirasa perlu upaya untuk melakukan pengkajian terhadap praktik implementasi kebijakan perlindungan konsumen di Kota Makassar secara integratif dan komprehensif serta dapat diterapkan secara efektif di masyarakat. Selain itu juga akan dilihat piranti hukum yang melindungi konsumen yang tidak dimaksudkan untuk mematikan usaha para pelaku usaha, tetapi justru sebaliknya perlindungan konsumen dapat mendorong iklim berusaha yang sehat yang mendorong lahirnya perusahaan yang tangguh dalam menghadapi persaingan melalui penyediaan barang dan/atau jasa yang berkualitas.

\section{METODE}

Jenis penelitian yang digunakan adalah penelitian deskriptif dengan pendekatan kualitatif, dimana penelitian tersebut digunakan untuk mengeksplorasi, 
menemukan, dan menjelaskan fenomena yang sedang terjadi, (Moleong:2005), dalam upaya pemerintah untuk memberikan perlindungan pada konsumen dengan menggunakan instrument kebijakan yang ada. Penelitian deskriptif adalah penelitian yang berupaya mengungkapkan suatu masalah dan keadaan sebagaimana adanya, untuk itu peneliti dibatasi hanya mengungkapkan faktafakta dan tidak menggunakan hipotesa.

Ruang lingkup penelitian ini yaitu Undang-Undang Nomor 9 Tahun 1999 Tentang Perlindungan Konsumen dimana dalam peraturan tersebut dituangkan secara jelas subtansi muatan, arah pengaturan dan jangkauan perngaturan. Unit analisis dalam penelitian ini adalah organisasi perangkat daerah yang membidangi perdagangan, dalam hal ini Dinas Perindustrian dan Perdagangan Kota Makasar.

\section{HASIL DAN DISKUSI}

Dinas Perindustrian dan Perdagangan kota Makassar merupakan salah satu unsur pelaksana Pemerintah kota di bidang Perindustrian dan Perdagangan. Hal ini tertuang dalam Peraturan Walikota No. 37 Tahun 2009 Tentang Uraian Tugas Jabatan Struktural pada Dinas Perindustrian dan Perdagangan merupakan unsur pelaksana Pemerintah kota di bidang Perindustrian dan Perdagangan dan Penanaman Modal. yang dipimpin oleh Kepala Dinas dan berkedudukan di bawah dan bertanggungjawab kepada Walikota melalui Sekretaris Kota.

$\begin{array}{clr}\text { Secara } & \text { spesifik pelaksanaan } \\ \text { penyelenggaran } & \text { perlindungan } & \text { konsumen }\end{array}$ berada pada Bidang Perlindungan Konsumen dan Kemeterologia, bidang ini mempunyai tugas melaksanakan pembinaan, perlindungan konsumen dan metrologian serta peredaran barang/jasa, dalam melaksanakan tugas bidang perlindungan dan kemetrologian menyelenggarakan membawahi tiga seksi yaitu Seksi
Perlindungan

Konsumen,

Seksi

Kemetrologian, dan Seksi Tertib Niaga dan Distribusi, adapun fungsi dari bidang ini dapat dirumuskan sebagai berikut :

1) Penyiapan bahan perumusan kebijaksanaan teknis kepastian hukum perlindungan konsumen dan kemetrologian legal.

2) Pelaksanaan penyiapan bahan penyusunan rencana dan program pembinaan penyelesaian sengketa konsumen.

3) Pelaksanaan bimbingan teknis tera dan tera ulang alat UPTD.

4) Pelaksanaan pembinaan tehadap penyelenggaraan perlindungan konsumen serta penerapan peraturan perundangudangan Pengolaan administrasi urusan terentu.

Peran Pemerintah Kota Makassar dibidang perlindungan konsumen dalam hal ini adalah Dinas Perindustrian Perdagangan dan Penanaman Modal, melaksanakan Low enforcement perangkat hukum dibidang konsumen agar tidak dengan mudahnya menjadi korban dari pelaku usaha yang tidak bertanggung jawab. Begitupun halnya dalam pembangunan dibidang perekonomian daerah bila diperlukan menerapkan sistem yang lebih menekankan aspek humanitas pelaku ekonomi (konsumen dan pelaku usaha) yakni perubahan perilaku dan cara berfikir ekonomi yang sehat, tidak hanya terjebak pada pembangunan aspek keuntungan saja akan tetapi keamanan dan keselamatan konsumen juga menjadi wajib untuk dilakukan.

Menurut Direktorat Jenderal Perlindungan Konsumen Kebijakan Perlindungan Konsumen secara nasional yang nantinya diteruskan ke daerah-daerah dilaksanakan sebagai berikut :

1) Regulatory Approach

Penerbitan dan penyempurnaan berbagai peraturan teknis, acuan dan pedoman pasca Undang-Undang Perlindungan Konsumen. Berdasarkan data yang 
penulis dapatkan, ada beberapa produk peraturan teknis yang telah ditelurkan pemerintah antara lain:

a) Keputusan Menteri Perindustrian dan Perdagangan RI Nomor 605/Mpp/Kep/8/2002 tentang pengangkatan Anggota Badan Penyelesaian Sengketa Konsumen Pada Pemerintah Kota.

b) Keputusan Menteri Perindustrian Dan Perdagangan RI Nomor 480/Mpp/Kep/6/2002 Tanggal 13 Juni 2002 tentang Perubahan Atas Keputusan Menteri Perindustrian dan Perdagangan Nomor 302/Mpp/Kep/10/2001 Tentang Pendaftaran Lembaga Perlindungan Konsumen Swadaya Masyarakat.

c) Keputusan Menteri Perindustrian dan Perdagangan RI Nomor: 302/Mpp/Kep/10/2001 tentang Pendaftaran Lembaga Perlindungan Konsumen Swadaya Masyarakat.

d) Peraturan Pemerintah Republik Indonesia Nomor 57 Tahun 2001 tentang Badan Perlindungan Konsumen Nasional.

e) Peraturan Pemerintah Republik Indonesia Nomor 58 Tahun 2001 tentang Pembinaan dan Pengawasan Penyelenggaraan Perlindungan Konsumen Presiden Republik Indonesia.

f) Peraturan Pemerintah Republik Indonesia Nomor 59 Tahun 2001 tentang Lembaga Perlindungan Konsumen Swadaya Masyarakat.

2) Social Enforcement Approach:

a) Pembudayaan kepada masyarakat.

b) Sosialisasi/publikasi.

c) Penguatan kapasitas kelembagaan Badan Penyelesaian Sengketa Konsumen dan Lembaga Perlindungan Konsumen Swadaya Masyarakat. d) Membangun connecting point dan partisipasi aktif dalam forum komunikasi lintas sektor dalam negeri dan luar negeri.

e) Membentuk motivator perlindungan konsumen. Berdasarkan informasi yang penulis dapatkan dari informan, bahwa tiap tahunnya Disperindag Kota Makassar, mengikutkan stafnya dalam pelatihan menjadi motivator perlindungan konsumen.

3) Law Enforcement Approach:

a) Ikut terlibat/aktif dalam kegiatan pengamatan pasar dan pengawasan barang beredar dan jasa.

b) Penyiapan Sumber Daya Manusia Mediator perlindungan konsumen.

c) Fasilitasi pengaduan konsumen (mediasi, konsiliasi).

d) Optimalisasi fungsi dan wewenang Badan Penyelesaian Sengketa Konsumen.

Implementasi perlindungan konsumen diantaranya dengan dibentuknya Badan Penyelesaian Sengketa Konsumen (BPSK) di Makassar yang keberadaannya diharapkan bisa menjadi media penyelesaian permasalahan transaksi antara produsen dan konsumen. Selain itu, juga terbuka bagi para LSM khususnya LSM yang berkonsentrasi pada masalah perlindungan konsumen yang dikenal dengan sebutan Lembaga Perlindungan Konsumen Swadaya Masyarakat (LPKSM).

Dengan ditindaknya beberapa kasus serta dengan berdirinya Badan Penyelesaian Sengketa Konsumen (BPSK) sesuai dengan Keputusan Presiden Nomor 90 Tahun 2001 Tentang Pembentukan Badan Penyelesaian Sengketa Konsumen pada pemerintah di daerah yang tujuannya agar menjadi payung mediasi bagi konsumen dan pelaku usaha, diharapkan dapat mengurangi, kasus-kasus yang berkepangjangan pada konsumen.

Bahkan diharapkan dengan menjalankan Keputusan Menteri 
Perindustrian dan Perdagangan Nomor 302/MPP/Kep/10/2001 tentang Pendaftaran Lembaga Perlindungan Konsumen Swadaya Masyarakat, maka Dinas Perindustrian Perdagangan dan Penanaman Modal juga akan mengeluarkan Tanda Daftar Lembaga Perlindungan Konsumen (TDLPK) sebagai syarat pendirian Lembaga Perlindungan Konsumen Swadaya Masyarakat. Legalisasi lembaga swadaya ini dilakukan agar selain mereka memiliki akses untuk menangani kasus-kasus perlindungan konsumen juga agar memudahkan pemerintah untuk meningkatkan profesionalisme masyarakat dengan memberi pembinaan-pembinaan langsung.

Proses implementasi kebijakan yang dimaksudkan adalah hal-hal yang dapat membantu atau mendukung terlaksananya sebuah program atau kebijakan sehingga tercapai apa yang telah disepakati. Di dalam proses implementasi suatu kebijakan membutuhkan proses yang secara seksama dapat diterapkan yang menunjang, seperti halnya kebijakan perlindungan konsumen tentunya ditunjang oleh beberapa faktor misalnya komunikasi, sumber daya, disposisi dan struktur birokrasi menurut George Edwards III (Winarno, 2005). Olehnya itu, untuk melihat bagaimana implementasi kebijakan perlindungan konsumen, berikut disajikan dalam pembahasan dimensi-dimensi implementasi.

\section{Dimensi Komunikasi}

Dalam implementasi kebijakan perlindungan konsumen tentunya komunikasi sangat penting dan mempunyai pengaruh. Mengkomunikasikan suatu kebijakan dimaksudkan agar ada kejelasan dari apa yang ingin dicapai dari kebiajakan tersebut. adapun indikator-indikator dalam faktor komunikasi adalah transmisi dimaksudkan bagaimana tahapan atau cara dalam penyampaian informasi dari pihak pembuat kebijakan dengan pihak pelaksana.
Bagaimana cara penyampaian informasi dari tingkat pusat ke daerah-daerah serta informasi ke konsumen langsung merupakan faktor penting dalam proses implementasi. Informasi itu dapat berupa lisan maupun tertulis. Informasi lisan yang penulis maksud berupa pertemuan-pertemuan sosialisasi, dan lain-lain. Sedangkan informasi tertulis yaitu informasi yang penyampaiannya melalui tulisan seperti surat edaran, faksimili, surat pemberitahuan, dan lain-lain.

Penulis menyimpulkan bahwa proses penyampaian informasi dari lembaga implementor dilakukan dengan cara mengadakan sosialisasi. Dimana sosialisasi tersebut diikuti oleh perwakilan masyarakat dan pelaku usaha. Kemudian Dinas Perindustrian dan Perdagangan Kota Makassar mensosialisasikannya lagi ketingkat masyarakat. Sosialisasi tersebut biasanya mengenai hal-hal yang sedang menghangat setahun belakangan misalnya kasus-kasus yang telah diinvetarisir oleh lembaga perlindungan konsumen, juga sosialisasi untuk mempersiapkan pengawasan barang beredar pada hari-hari besar.

Berdasarkan rangkuman hasil wawancara diperoleh informasi bahwa upaya Dinas Perindustrian dan Perdagangan Kota Makassar dalam menberikan kejelasan informasi kepada masyarakat ditempuh dengan berbagai macam program termasuk memberikan penyuluhan kepada pelaku usaha dan konsumen, agar mereka dapat memahami pentingnya pemberian perlindungan konsumen.

Jawaban berbeda diungkapkan salah satu konsumen carrefour yang ditemui dilapangan dari keterangan konsumen dapat disimpulkan bahwa dari sisi konsumen, penyampaian informasi mengenai perlindungan konsumen belum tersampaikan dengan jelas kepada masyarakat, bahkan ketika ada informasi yang diperoleh hanya bersumber dari media elektronik, itupun hanya ketika ada kasus-kasus tertentu yang 
sedang hangat diperbincangkan. Apabila dianalisis lebih dalam informasi diatas dapat dideskripsikan bahwa pada umumnya masyarakat tidak memiliki cukup referensi untuk melindungi diri dari barang-barang yang dikonsumsi.

\section{Dimensi Sumberdaya}

Kekurangan sumber daya yang diperlukan untuk mengimplementasi kebijakan maka dapat implementasi dipastikan tidak akan berjalan sesuai dengan apa yang diinginkan. Sumber daya. Sumber daya memegang peranan penting, karena implementasi kebijakan tidak akan efektif bilamana sumber-sumber pendukungnya tidak tesedia.

Ketersediaan sumber daya dalam melaksanakan sebuah program merupakan salah satu faktor yang harus selalu diperhatikan, jika kebijakan tersebut diinginkan terlaksana sebagaimana yang telah direncanakan. Dalam hal ini sumber daya yang dimaksud adalah Sumber Daya Manusia (SDM) dari pelaksana kebijakan baik itu secara kualitas maupun kuatitasnya.

Faktor manusia dalam keberhasilan suatu kebijakan menjadi salah satu faktor penentu, manusia sebagai salah satu resource merupakan instrumen yang menjadi penggerak dari kegiatan implementasi, ketersediaan Jumlah staf dan mutu serta keahlian-keahlian yang dimiliki staf harus memadai, sesuai dengan bidang kerjanya masing-masing. Seperti halnya dalam pengimplementasian kebijakan perlindungan konsumen juga harus didukung oleh staf yang tidak hanya memadai akan tetapi memiliki keahlian atau setidaknya memahami kebijakan tersebut agar implementasinya berjalan sesuai dengan apa yang diinginkan.

Sumber daya manusia dalam hal ini staf masih bisa dikatakan kurang, baik dari kuantitas maupun kualitasnya. Perbandingan antara jumlah tenaga yang minim tidak sesuai dengan luasnya daerah kerja, begitu pula dalam hal mutu pegawai, kompetensi pegawai dalam menyelesaikan persolan secara langsung dilapangan masih sangat kurang, sehingga ketika ada temuan dan aduan dari konsumen, selalu diteruskan ke Diperindag, padahal hal tersebut bisa saja dilakukan oleh penyidik pegawai negeri sipil (PPNS). Hal ini butuh perhatian khusus untuk meningkatkan baik kuantitas maupun kualitasnya, sehingga sumberdaya sebagai penujang implementasi kebijakan bisa berjalan maksimal.

Sesuai dengan teori Edward III bahwa sumber daya utama dalam implementasi kebijakan adalah staf. Kegagalan yang sering terjadi dalam implementasi kebijakan salah satunya disebabkan oleh karena staf yang tidak mencukupi, memadai, ataupun tidak kompeten dibidangnya. Pada Dinas Perindustrian dan Perdagangan maupun BPOM jumlah staf yang dimiliki sangat terbatas/tidak cukup sehingga dalam menjalankan kebijakan. Berdasarkan data sekunder yang diperoleh dari Disperindag Kota Makassar, jumlah pegawai khusus penempatan pada bidang perlindungan konsumen masih sangat minim, untuk lebih jelasnya diuraikan, pada tabel berikut :

Tabel 1

Keadaan Pegawai pada Bidang Perlindungan Konsumen berdasarkan Tingkat Pendidikan dan Status

\begin{tabular}{|c|c|c|c|}
\hline No & $\begin{array}{c}\text { Jenjang } \\
\text { Pendidikan }\end{array}$ & Jumlah & Status \\
\hline 1. & SMU & 2 & Tenaga Organik \\
\hline 2. & DIII & 0 & 11 Orang \\
\hline 3. & S I & 9 & Tenaga Kontrak \\
\hline 4. & S II & 2 & 3 Orang \\
\hline \multicolumn{3}{|c|}{ Jumlah } & 13 Orang \\
\hline
\end{tabular}
Sumber: Data Sekunder, Disperindag, 2019

Berdasarkan tabel 1, diketahui bahwa jumlah pegawai pada Bidang Perlindungan Konsumen sebanyak 13 orang, jumlah tersebut sangat tidak memadai untuk melaksanakan seluruh tugas memberikan perlindungan pada konsumen dikota Makassar, begitu pun dari tingkat pendidikan pegawai, masih ada 2 orang diantaranya yang memiliki tingkat pendidikan SMU sebanyak 2 
orang. Dari segi ketersediaan staf sangat nampak kurang menunjang, ditambah kompetensi pegawai dalam memberikan solver pada kasus-kasus perlindungan konsumen juga belum optimal.

Dalam teori Edward mengemukakan bahwa sumberdaya manusia memiliki indikator diantaranya termasuk soal kewenangan pada umumnya kewenangan harus bersifat formal agar perintah dapat dilaksanakan. Kewenangan merupakan otoritas atau legitimasi bagi para pelaksana dalam melaksanakan kebijakan yang ditetapkan secara politik. Dari pengamatan peneliti, begitu banyak kasus yang seharusnya butuh penaganan serius. Contoh kasus pada peristiwa air mineral Merk Aqua yang ditemukan berlumut, kasus gula rafinasi, peredaran jamu ilegal sampai kasus yang masih hangat diberitakan di media massa yaitu 70 kosmetik berbahaya. Namun kenyataannya sampai saat ini kita sebagai konsumen belum pernah melihat ataupun mendengar penindakan tegas secara hukum sampai penutupan pabriknya. Berdasarkan pengamatan serta data yang penulis dapatkan dari, salah satu toko parfumed yang baru-baru ini di dapati melakukan pencampuran parfumed tanpa izin resmi serta ditemukan sedikitnya 80 parfumed tanpa registrasi dalam negeri masih beroperasi seperti biasa. Dari data tersebut jelas kewenangan yang dimiliki implementor kebijakan ini seakan-akan hanya hiasan saja, karena sampai saat ini tindakannya hanya sampai penyitaan produk saja.

\section{Dimensi Disposisi/Sikap Pelaksana Kebijakan}

Disposisi adalah sikap dan dukungan dari para aparat pelaksana terhadap program atau kebijakan yang akan dijalankan. Sikap dan dukungan sangat penting dalam proses impplementasi, karena kesamaan pandangan terhadap apa yang dikerjakan bersama akan mempermudah pencapaian tujuan. Bila para pelaksana atau implementor kebijakan terpecah belah dalam hal sikap dan dukungan tersebut maka apa yang akan dicapai dari suatu kebijakan tidak akan tercapai secara efisien dan efektif, karena akan menghadapai banyak rintangan dan kendala dari aparat pelaksana kebijakan itu sendiri. Pentingnya kesamaan pandangan terhadap suatu program yang sedang dilaksanakan akan terlihat dari kesatuan arah dan gerak dari para pelaksana kebijakan. Dengan adanya kesamaan gerak dalam pelaksanaan kebijakan, maka diharapkan tujuan dari sebuah kebijakan sebagai sasaran yang hendak dicapai bukanlah hanya semata-mata sebuah cita-cita melainkan merupakan sebuah kenyataan. Disposisi pada dasarnya merupakan sikap attitude dari pelaksana kebijakan baik dalam pendekatan penempatan birokrat (staffing the bureaucracy) dan insentif yang diberikan, kepada pegawai dalam rangka mendorong manusia dalam lembaga implementor agar mau bekerja secara maksimal.

Bahwa untuk menjadi penyidik perlindungan konsumen (implementor) atau PPNSPK, penyidik perlindungan konsumen pegawai negeri sipil, staf diwajibkan mengikuti pelatihan/pengujian di Jakarta, dimana mekanisme seleksinya cukup ketat dengan potensi kelulusan sangat kecil, Indonesia saat ini mengalami kekurangan tenaga PPNSPK, jumlah tenaga hanya berkisar 671 orang disuluruh indonesia, dengan presentasi perekrutan hanya sekitar 90 orang pertahun, salah satu kriteria yang wajib dipenuhi oleh para implementor kebijakan perlindungan konsumen pada Dinas Perindustrian dan Perdagangan Kota Makassar adalah dengan melewati seleksi persyaratan tertentu. Hal ini menunjukkan bahwa sikap komitmen pemerintah Kota Makassar dalam hal ini Disperindag Kota Makassar memiliki komitmen dan kemauan yang kuat untuk mewujudkan tenaga SDM yang menunjang implementasi kebijakan. 
Selain itu pemberian insentif kepada pegawai adalah penghargaan yang diberikan kepada pelaksana jika berhasil dalam melaksanakan tugas-tugas yang diberikan hal ini dalam bentuk reward dan pemenuhan kepentingan pribadi (self interest). Mengubah personil dalam birokrasi pemerintah merupakan pekerjaan yang sulit dan tidak mudah, dibutuhkan strategi dan motivasi dalam bentuk insentif untuk mendorong aktualisasi pribadi agar mau bekerja secara maksimal karena, apabila pegawai tidak memiliki motivasi yang kuat maka tidak menjamin proses implementasi dapat berjalan lancar.

Berdasarkan rangkuman wawancara, Dinas Perindustrian dan Perdagangan Kota Makassar, dari segi pemberian insentif belum dilakukan sebagai media untuk memotivasi pegawai dalam menjalankan tugas bahkan pegawai masih kekurangan biaya operasional yang lebih dikarenakan wilayah kerjanya cukup luas, menurut keterangan diatas juga diketahui bahwa salah satu harapan petugas yaitu adanya pemberian insentif ataupun reward kepada mereka setelah memecahkan kasus-kasus tertentu, sehingga mereka memiliki motivasi yang kuat untuk bekerja dalam menemukan kasus-kasus pelanggaran konsumen.

Hal ini sejalan dengan teori Edward III (Winarno, 2005) bahwa salah satu teknik yang disarankan untuk mengatasi masalah kecenderungan para pelaksana adalah dengan memanipulasi insentif, maksudnya adalah insentif yang diberikan kepada pelaksana bisa dikemas dalam pemberian reward apabila tercapainya prestasi-prestasi tertentu. Bagi penulis, dengan cara menambah keuntungan atau biaya tertentu, mungkin akan mendorong para pelaksana kebijakan melaksanakan perintah dengan lebih baik lagi. Informasi yang penulis dapatkan bahwa adanya gaji tambahan yang diperoleh hanya didapatkan melalui honor-honor kegiatan yang bersifat seremonial itupun jumlahnya tidak besar karena sebatas honor kepanitiaan.

\section{Dimensi Struktur Birokrasi}

Adapun faktor terakhir yang berpengaruh dalam implementasi kebijakan perlindungan konsumen adalah struktur birokrasi. Para implementor mungkin tahu apa yang harus dikerjakan dan juga memiliki keinginan untuk melakukan namun mereka terhambat pada struktur organisasi pelaksana, Dalam hal ini, struktur birokrasi yang dimaksudkan adalah standar pengelolaan dan prosedur atau alur kerja untuk mengatur tata aliran pekerjaan dalam pelaksanaan program

Berdasarkan intisari wawacara serta data sekunder berupa buku bahan panduan perlindungan konsumen penulis menyimpulkan bahwa cara atau alur kerjanya yaitu mulai dari pengawasan, dengan mengawasi peredaran barang, dalam hal ini biasa bekerjasama dengan pihak-pihak terkait. Selanjutnya tindak lanjut, hasil pengawasan akan ditindak lanjuti dengan melakukan penyelidikan mengenai indikasiindikasi penyimpangan. Hal ini bisa berasal dari aduan masyarakat serta rekomendasi atau temuan instansi lain. Selain itu, apabila temuan tersebut benar mengarah pada indikasi pelanggaran, maka akan diberikan tindakan hukum.

Dari mengumumkan public warning sampai pelarangan beredar. Namun untuk temuan produk skala nasional akan diteruskan ke tingkat pusat. Sesuai dengan yang dikemukakan oleh Edward III (Winarno, 2005) bahwa implementasi akan gagal apabila struktur birokrasi yang ada menghalangi koordinasi yang diperlukan dalam melaksanakan kebijakan. Kebijakan yang komplek membutuhkan kerjasama banyak orang, serta pemborosan sumberdaya akan mempengaruhi hasil implementasi. Perubahan yang dilakukan tentunya akan mempengaruhi individu dan secara umum akan mempengaruhi sistem dalam birokrasi. 
Dinas Perindustrian dan Perdagangan selaku pelaksana kebijakan telah melakukan prosedur dalam menjalankan implementasi kebijakan perlindungan konsumen, karena Dinas Perindustrian dan Perdagangan melakukan proses penyidikan, pengawasan sampai penindakan terkait atas temuan kasus perlindungan konsumen.

Penulis menyimpulkan bahwa perlindungan konsumen dijalankan berdasarkan struktur yang ada pada Disperindag. Adapun biasa dilaksanakan koordinasi bersama pihak-pihak terkait lainnya yang disebut Operasi Gabungan Nasional (Obganas) yang dilakukan serentak. Sesuai dengan tugas, pokok dan fungsi dari masing-masing sub dinas, dalam hal ini Sub Dinas Perdagangan Dalam Negeri. Adapun sub dinas ini dapat berkoordinasi dengan pihak-pihak terkait baik intern maupun ektern. Menurut Edward III, (Winarno, 2005) bahwa kebijakan yang begitu kompleks menuntut adanya kerjasama banyak orang. Birokrasi sebagai pelaksana sebuah kebijakan harus dapat mendukung kebijakan yang telah diputuskan dengan jalan melakukan koordinasi yang baik. Struktur dalam Dinas Perindustrian dan Perdagangan mengenai penanganan perlindungan konsumen sangat jelas, karena untuk perlindungan konsumen sendiri sudah menjadi wewenang dari Sub Dinas Perdagangan Dalam Negeri, selain itu dilakukan juga koordinasi dengan beberapa instansi yang terkait seperti BPOM, Dinas Kesehatan, dan lain-lain.

\section{KESIMPULAN}

Implementasi perlindungan konsumen di Kota Makassar diselenggarakan berdasarkan Undang-Undang Nomor 8 Tahun 1999 Tentang Perlindungan Konsumen, yang ditujukan untuk memberikan jaminan kepada masyarakat sebagai pengguna akhir dari sebuah barang dan jasa yang disediakan oleh produsen, kurangnya kesadaran konsumen dalam memahami hak-haknya

menjadikan

konsumen seringkali menjadi korban dari produsen yang tidak bertanggung jawab, lemahnya nilai posisi konsumen Obat dan Makanan untuk mendapatkan haknya menjadi sebuah problem yang harus ditangani oleh pemerintah, sehingga pemerintah Kota Makassar melalui Dinas Perindustrian dan Perdagangan Kota Makassar sebagai implementor kebijakan perlindungan konsumen menyelenggarakan upaya perlindungan konsumen melalui berbagai upaya. Teori Edward III digunakan untuk melakukan analisis ilmiah mengenai proses implementasi kebijakan perlindungan konsumen, melalui empat indikator yaitu komunikasi, Sumber daya, Disposisi dan Struktur Birokrasi, temuan hasil penelitian menunjukkan bahwa pada prinsipnya implementasi perlindungan konsumen di Kota Makassar berdasarkan empat indikator tersebut telah berjalan dengan baik.

\section{REFERENSI}

Hornby. 2005. Oxford Advance Learner's Dictionary of Current. English, Oxford University Press.

Moleong, Lexy J. 2005. Metodologi Penelitian Kualitatif. Bandung, PT Remaja Rosda Karya.

Keputusan Menteri Perindustrian Dan Perdagangan RI Nomor 480/Mpp/Kep/6/2002 Tanggal 13 Juni 2002 tentang Perubahan Atas Keputusan Menteri Perindustrian Dan Perdagangan Nomor 302/Mpp/Kep/10/2001 Tentang Pendaftaran Lembaga Perlindungan Konsumen Swadaya Masyarakat.

Keputusan Menteri Perindustrian Dan Perdagangan Republik Indonesia Nomor : 302/Mpp/Kep/10/2001 tentang Pendaftaran Lembaga Perlindungan Konsumen Swadaya Masyarakat. 
Keputusan Presiden Nomor 90 Tahun 2001

tentang Pembentukan Badan Penyelesaian

Sengketa Konsumen.

Peraturan Pemerintah Republik Indonesia

Nomor 57 Tahun 2001 tentang Badan

Perlindungan Konsumen Nasional.

Peraturan Pemerintah Republik Indonesia

Nomor 58 Tahun 2001 tentang Pembinaan dan Pengawasan

Penyelenggaraan Perlindungan Konsumen

Presiden Republik Indonesia.

Peraturan Pemerintah Republik Indonesia

Nomor 59 Tahun 2001 tentang Lembaga

Perlindungan Konsumen Swadaya

Masyarakat.

Peraturan Walikota No 37 Tahun 2009 tentang Uraian Tugas Jabatan Struktural pada Dinas Perindustrian dan Perdagangan.

Resolusi Perserikatan Bangsa-bangsa Nomor 39/248 Tahun 1985 tentang Perlindungan Konsumen (Guidelines for Consumer Protection).

Winarno, Budi. 2008. Kebijakan Publik (Teori dan Proses). Jakarta, Media Pressindo.

Undang-Undang Republik Indonesia Nomor 8 Tahun 1999 tentang Perlindungan Konsumen. 